\title{
Blockade of Endothelin-1 with a Novel Series of 1,3,6-Trisubstituted-2-Carboxy-Quinol-4-Ones Controls Infection-Associated Preterm Birth
}

Nicole S. Olgun, Hardik J. Patel, Ralph Stephani, Istvan Lengyel, and Sandra E. Reznik

From the College of Pharmacy and Allied Health Professions, St. John's University, Jamaica, New York

Preterm birth (PTB) currently accounts for $13 \%$ of all births in the United States, with the leading cause of PTB being maternal infection. Endothelin-1, an extremely potent vasoconstrictor capable of increasing myometrial smooth muscle tone, has been shown to be up-regulated in the setting of infection in pregnancy, ultimately leading to PTB. In previous work, we have shown that infection-associated PTB is controlled in our murine model by using phospharamidon, an endothelin-converting enzyme-1 inhibitor; knocking down endothelin-converting enzyme-1 mRNA; or blocking the binding of endothelin- 1 to the endothelin-A $\left(E T_{A}\right)$ receptor with either BQ-123 or with HJP-272, the 6-OH compound of our series of novel synthetic $\left(\mathrm{ET}_{\mathrm{A}}\right)$ receptor antagonists. In the current study, we show that HJP-272, a highly selective $\mathrm{ET}_{\mathrm{A}}$ receptor antagonist with an $\mathrm{IC}_{50}$ of $70.1 \mathrm{nmol} / \mathrm{L}$, binds in a noncompetitive manner to the $\mathrm{ET}_{\mathrm{A}}$ receptor. Additionally, we introduce $n$-propyl (HJP-286) and $n$-butyl (HJP-278) analogs of HJP-272. We find that the $\mathrm{LD}_{50}$ of HJP-272, the analog in the series most effective in controlling preterm birth, is more than 20-fold higher than its therapeutic dose. Acute exposure to high doses of these compounds produces no histological changes in any organ, while chronic exposure produces only a rare hepatotoxic effect. These findings may be of clinical significance, as there is currently no FDA-approved therapy for women presenting with threatened preterm delivery. (Am J Pathol 2010, 177:1929-1935; DOI: 10.2353/ajpath.2010.100281)

Preterm birth (PTB) is defined as any delivery occurring before the completion of 37 weeks' gestation, and currently accounts for 12 to $13 \%$ of all births in the United States. Despite advances that have been made in our understanding of the mechanisms involved in parturition, the occurrence of PTB has not declined and is responsible for approximately 5000 infant deaths per year. ${ }^{1}$

In the clinical setting, inhibition of myometrial contractions (tocolysis) is the focus of therapeutic approaches for preventing PTB since the contracting uterus is the most commonly recognized precursor of an early delivery. ${ }^{2}$ While there is currently no FDA-approved treatment for PTB, more than $98 \%$ of polled obstetricians in the United States reported that they use tocolytic agents in patients in preterm labor before 32 weeks of gestation, despite their questionable efficacies. ${ }^{3}$

The single most common cause of spontaneous PTB in the United States, aside from a previous premature delivery, is intrauterine infection in the mother (40\%). The noted presence of bacteria and infection in the gestational compartment and other areas of pregnant women have been shown to trigger the immune system via cell surface recognition molecules such as Toll-like receptors. ${ }^{4}$ The binding of Toll-like receptor-4 initiates a host inflammatory response involving cytokines such as interleukin-1 and tumor necrosis factor, thus playing a critical role in the pathogenesis of infection-associated PTB. ${ }^{5-8}$

Composed of 21 amino acid residues with two sets of intrachain disulfide linkages, the human endothelin peptides include three distinct isoforms, produced in an array of tissues with different distribution patterns and involved in regulation of vasomotor tone, cell proliferation, and hormone function. ${ }^{9-11}$ Endothelin-1 (ET-1) is the most potent vasoconstrictor in the ET family and is also the only member to be produced in endothelial cells. ${ }^{10}$

Two types of ET receptors, endothelin- $A\left(E T_{A}\right)$ and endothelin-B $\left(E T_{B}\right)$, have been identified in most mammalian species and belong to the superfamily of G-protein-coupled receptors. ${ }^{11}$ While the $\mathrm{ET}_{\mathrm{A}}$ receptor has a

\footnotetext{
Supported by a St. John's University seed grant (S.E.R.).

Accepted for publication June 24, 2010.

Address reprint requests to Sandra E. Reznik, M.D., Ph.D., Associate Professor, St. John's University, Department of Pharmaceutical Sciences, 8000 Utopia Parkway, St. Albert Hall, G018-B, Queens, NY 11439. E-mail: rezniks@stjohns.edu.
} 
much greater affinity for ET-1 as compared with ET-2 and $E T-3$, the $\mathrm{ET}_{\mathrm{B}}$ receptor binds all three members with equal affinity. ${ }^{11}$ The $\mathrm{ET}_{\mathrm{A}}$ receptor is expressed predominantly in vascular smooth muscle cells and cardiac myocytes. ${ }^{12}$

ET-1 is now implicated in an ever-growing list of pathological processes, ranging from pulmonary hypertension to cancer. In particular, several lines of evidence support the involvement of the peptide in obstetrical disorders. Elevated levels of placental endothelin have been observed in third trimester preterm births associated with hypoxia. ${ }^{13}$ We have previously reported that endothelinconverting enzyme-1, the enzyme that synthesizes ET-1, co-localizes with its substrate in the placenta ${ }^{14}$ and that the endothelin-converting enzyme-1 inhibitor phosphoramidon controls PTB in a murine model of infectionassociated preterm labor. ${ }^{15}$ Subsequently, we have also shown that endothelin-converting enzyme-1 is up-regulated in the mouse model of PTB and that preterm delivery is controlled by silencing endothelin-converting enzyme-1 mRNA with the commercially available $\mathrm{ET}_{\mathrm{A}}$ receptor antagonist (ETA-RA) BQ123 and with HJP-272, a highly selective $E T_{A}$ receptor antagonist synthesized by our group. ${ }^{16,17}$

In the present work, we test several analogs of our series of novel selective $\mathrm{ET}_{\mathrm{A}}-\mathrm{RA}$ in the mouse model and show that we are able to prevent PTB by blocking $\mathrm{ET}_{\mathrm{A}}$ receptors with doses of our compounds that fall far below the toxic range. Although ET-1 plays a critical role in inflammatory cascade-associated PTB, the use of existing $E T_{A}$ receptor antagonists as a form of tocolytic therapy remains controversial due to the fact that ET-1-deficient mice have marked developmental abnormalities ${ }^{18}$ and currently available ET-1 antagonists are pregnancy category $X$ drugs. Therefore, the introduction of highly effective endothelin blocking agents with low levels of toxicity would have significant impact on the management of a very important clinical problem.

\section{Materials and Methods}

Membrane preparations for the $\mathrm{ET}_{\mathrm{A}}$ receptors (Bio-Xtal) were purchased from Axxora (Switzerland). $\left[{ }^{125} \mid\right]$ Tyr 13-ET1 (human, porcine) was obtained from PerkinElmer, and ET-1 (human, porcine) was purchased from Sigma Chemicals (St. Louis, $\mathrm{MO}$ ). The selective $\mathrm{ET}_{\mathrm{A}}$ receptor antagonists HJP-272 (6-OH), HJP-286 (6-O-n-propyl), and HJP-278 (6O-n-butyl) were synthesized as previously reported and have $K_{\mathrm{i}}$ values in the nanomolar range ${ }^{19}$ (available from http://www.et-10.it/docs/Abstracts_ET10.pdf, last accessed August 15, 2010; Figure 1). The infrared, $\left[{ }^{1} \mathrm{H}\right] \mathrm{NMR}$ and $\left[{ }^{13} \mathrm{C}\right]$ NMR of these compounds were consistent with assigned structures. Elemental analysis was performed by Atlantic Microlabs (Norcross, GA) and all analogs gave satisfactory elemental analysis of $\mathrm{C}, \mathrm{H}$, and $\mathrm{N}( \pm 0.4 \%)$. All other reagents were purchased from Calbiochem, EMD, VWR International, Sigma Chemicals, and Fisher Scientific.<smiles>CCc1cc2c(cc1Cn1c(C(=O)O)c(Cc3cccc(C(=O)O)c3)c(=O)c3cc(O)ccc31)OCO2</smiles>

\begin{tabular}{|c|c|}
\hline$\underline{\mathbf{R}}$ & Compound \\
\hline $\mathbf{H}$ & HJP-272 \\
\hline n-C ${ }_{3} \mathrm{H}_{7}$ & HJP-286 \\
\hline n-C $\mathrm{C}_{4} \mathrm{H}_{9}$ & HJP-278 \\
\hline
\end{tabular}

Figure 1. Chemical structure of novel 1,3,6,-trisubstituted-2-carboxy-quinol4-one ET -RAs. The selective ET - -RAs HJP-272 (6-OH), HJP-286 (6-O- $n$ propyl), and HJP-278 (6-O- $n$-butyl) were synthesized as previously reported and have $K_{\mathrm{i}}$ values in the nanomolar range.

\section{Competition Binding Assay}

To determine the receptor binding characteristics of our compounds, concentrations of [ ${ }^{125}$ I]Tyr13-ET-1 ranging from $6 \mathrm{pmol} / \mathrm{L}$ to $1425 \mathrm{pmol} / \mathrm{L}$ were incubated with $5 \mu \mathrm{g}$ of $\mathrm{ET}_{\mathrm{A}}$ receptor and buffer $\left(50 \mathrm{mmol} / \mathrm{L} \mathrm{NaH} \mathrm{PO}_{4}, 50 \mathrm{mmol} / \mathrm{L}\right.$ $\mathrm{NaCl}, 5 \mathrm{mmol} / \mathrm{L}$ EDTA, $1 \mathrm{~g} / \mathrm{L}$ bovine serum albumin) for 2 hours at a constant temperature of $30-32^{\circ} \mathrm{C}$ with and without a constant concentration of HJP-272 (225 pmol/ L). Nonspecific binding was completed by the addition of $300 \mathrm{nmol} / \mathrm{L}$ ET-1. Specific binding was calculated by subtracting the value of nonspecific binding from total binding. The final volume in each tube was $200 \mu \mathrm{l}$. Assays were stopped as previously described. ${ }^{17}$ Counts per minute were calculated for all data points, and assays were performed in duplicate.

\section{Animals}

C57Bl/6 mice from Taconic Laboratories were used for all experiments. Animals were housed in plastic cages in a temperature and humidity controlled facility, with 12 hour light-12 hour dark cycles, and allowed ad libitum access to food and water. All experimental protocols were approved by the St. John's University Animal Care and Utilization Committee of the College of Pharmacy and Allied Health Professions. Research was conducted according to the National Institutes of Health Guide for the Care and Use of Laboratory Animals (http://www.nap.edu/openbook.php? record_id $=5140$, last accessed on August 15, 2010).

\section{Tocolysis Study}

Fifty timed pregnant mice were stimulated with $10.0 \mathrm{mg} / \mathrm{kg}$ lipopolysaccharide (i.p.) at E15.5. Ten were treated with phosphate buffered saline $(0.5 \mathrm{ml}$, i.p.), 10 were treated with potassium hydroxide $(\mathrm{KOH})$-potassium carbonate $\left(\mathrm{K}_{2} \mathrm{CO}_{3}\right)$ vehicle $(0.5 \mathrm{ml}$, i.p.), 10 were treated with $50 \mathrm{mg} / \mathrm{kg}$ of HJP-272 (0.5 ml, i.p.), ten were treated with $50 \mathrm{mg} / \mathrm{kg}$ HJP286 (0.5 ml, i.p.), and 10 were treated with $50 \mathrm{mg} / \mathrm{kg} \mathrm{HJP}$ - 
278 (0.5 ml, i.p.). All mice were observed for PTL for a period of 24 hours. After delivering, or at 24 hours after lipopolysaccharide administration for mice that did not deliver, all mice were sacrificed and necropsies were performed to confirm pregnancy and to count the number of pups retained in utero.

\section{$L D_{50}$ Studies}

Based on in vitro activity shown in previous experiments, the 6-OH analog (HJP-272) and the 6-O-n-propyl analog (HJP-286) have the greatest affinity for the $\mathrm{ET}_{\mathrm{A}}$ receptor (manuscript in preparation). $L D_{50} s$ were therefore determined for these two analogs, according to the Organization for Economic Development 423 guidelines (Acute Toxic Class Method), with slight modifications (http://iccvam. niehs.nih.gov/SuppDocs/FedDocs/OECD/OECD_GL423.pdf, last accessed on August 15, 2010). Doses were changed from $300 \mathrm{mg} / \mathrm{kg}$ to $200 \mathrm{mg} / \mathrm{kg}$ and from $2000 \mathrm{mg} / \mathrm{kg}$ to $1000 \mathrm{mg} / \mathrm{kg}$. In both sets of $L D_{50}$ determinations, the starting dose was $200 \mathrm{mg} / \mathrm{kg}$. Doses were administered into the intraperitoneal cavity.

After an observation period of 24 hours or immediately after euthanizing any moribund animals, necropsies were performed and all vital organs were harvested in $10 \%$ neutral buffered formalin for further histological evaluation. Mice were sacrificed by carbon dioxide asphyxiation.

\section{Rotorod Testing}

Mice were placed on a rotorod 8 inches above a cage filled with bedding to catch any falling animals. The rotorod was set to a speed of 15 revolutions per minute. For a mouse to be considered properly trained, it had to maintain its balance and stay on without falling, for 2 minutes. Each time a mouse fell it was given a 5-second rest before being placed back on. The number of attempts it took each mouse to remain on the rotorod for 2 uninterrupted minutes was recorded.

Once able to remain on the rotorod for 2 minutes, mice were injected with $0.5 \mathrm{ml} \mathrm{PBS}, \mathrm{KOH}-\mathrm{K}_{2} \mathrm{CO}_{3}$ vehicle, or with one of the analogs. Dosing of the two compounds was between 200 and $1000 \mathrm{mg} / \mathrm{kg}$. Mice were then allowed to rest for 30 minutes. After 30 minutes, the animals were then placed on the rotorod again and observed. This time, in order for mice to be considered as having passed, they were required to stay on for 1 minute, and were allowed two falls within the 1-minute time period. Animals were also checked for loss of grasping and loss of righting reflexes. Testing was then conducted at $t=2$, $6,12,18$, and 24 hours after the first injection. Any animal that died during the 24-hour period was necropsied. At the end of 24 hours, with the exception of animals that died during the experimental period, animals were sacrificed by carbon dioxide asphyxiation and all vital organs were harvested and stored as mentioned previously.

\section{Histology}

For histological analysis of acute effects of exposure to HJP-272 and HJP-276, groups of three mice each were treated with PBS, vehicle, or one of five concentrations of either compound, ranging in dose from 200 to 1000 $\mathrm{mg} / \mathrm{kg}$ and injected intraperitoneally (36 mice in total). Mice were euthanized after 24 hours and necropsy was performed immediately. All vital organs were collected and stored in 10\% neutral buffered formalin for at least 24 hours. As testing for tocolytic effects of the novel ET-R receptor antagonists revealed that HJP-272 was the most effective analog, the chronic effect of exposure to this compound was also evaluated. Groups of two to three mice were treated with vehicle, 200,400 , and $800 \mathrm{mg} / \mathrm{kg}$ HJP-272 injected i.p. (10 mice in total). Mice were then sacrificed 10 days later. For evaluation of hepatotoxicity, the number of lymphoid aggregates, ie, collections of 10 or more lymphocytes, under the 10X low power objective and the number of rows of lymphocytes in the three largest aggregates were determined and averaged in all sections of liver. The chronic inflammatory index was found for each section by multiplying the average number of lymphoid aggregates present by the average number of rows of lymphocytes in the three largest aggregates. For all tissue sections, fixed tissues were dehydrated and paraffin embedded, sectioned at $4 \mu \mathrm{m}$ and stained with hematoxylin and eosin. All slides were examined by three blinded observers.

\section{Statistical Analysis}

The statistical significance of the effect of each compound on rotorod performance was determined by the Fisher's exact test. Differences in chronic inflammatory index among liver sections from mice exposed to each compound were tested for statistical significance with the Student's $t$-test. The effect of each treatment on delivery time and on percent pups delivered was evaluated with the $\chi^{2}$ test. Results were considered significant for $P$ values $<0.05$.

\section{Results}

\section{Competitive Binding Assay}

As HJP-272, the hydroxyl analog, is both the least toxic and most efficacious in the series (see below), a competitive binding assay was developed with this compound. The dissociation constant $\left(K_{\mathrm{d}}\right)$ value of $\left[{ }^{125} \mathrm{I}\right] \mathrm{Ty}$ r13-ET-1 for the $\mathrm{ET}_{\mathrm{A}}$ receptors expressed in the membrane preparation, in the absence of HJP-272 is $0.232 \mathrm{nmol} / \mathrm{L}\left(R^{2}=\right.$ 0.9751 ) with a maximum binding $\left(B_{\max }\right)$ value of 102,922 cpm $\left(R^{2}=0.9432\right)$ (Figure $\left.2 A\right)$. In the presence of a constant concentration (225 pmol/L) of HJP-272 in the assay mix, the $K_{d}$ value equals $0.363 \mathrm{nmol} / \mathrm{L}\left(R^{2}=\right.$ 0.9432 ) (Figure 2B). Statistical analysis using Prism software reports that there is no significant difference in the $K_{\mathrm{d}}$ value calculated in the absence or presence of compound, and there is no shift in the binding curve. How- 
A

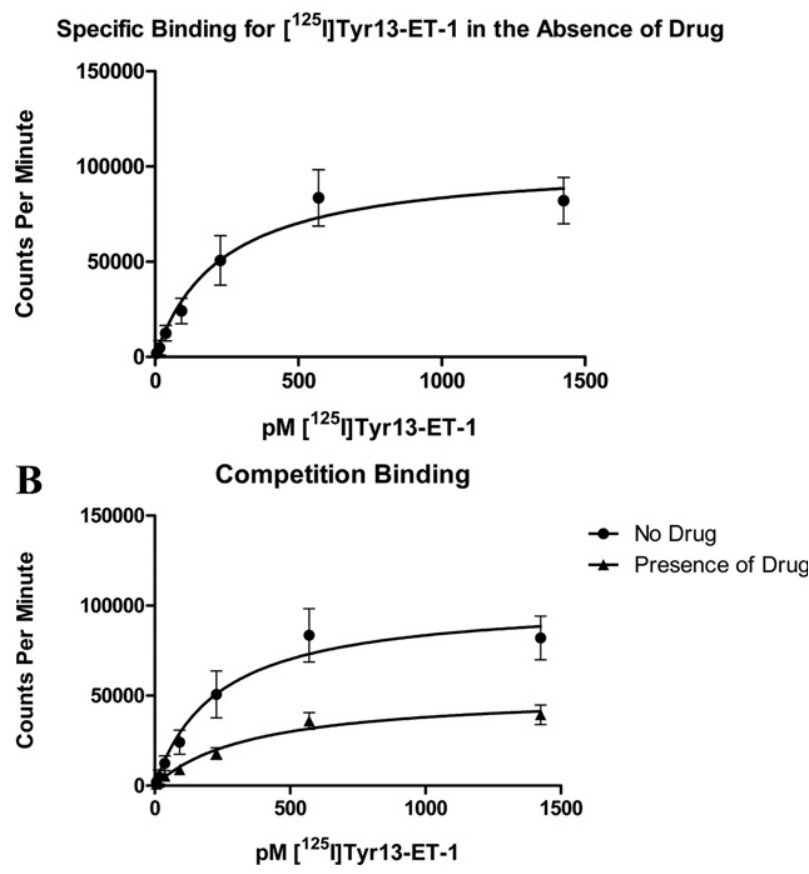

Figure 2. HJP-272 binds noncompetitively to $\mathrm{ET}_{\mathrm{A}}$ receptor. Membranes enriched in $\mathrm{ET}_{\mathrm{A}}$ receptors were incubated with increasing concentrations of $\left[{ }^{125} \mathrm{I}\right] \mathrm{Tyr} 13-\mathrm{ET}-1$ for 2 hours at a constant temperature of $30-32^{\circ} \mathrm{C}$. in the absence (A) or presence $(\mathbf{B})$ of a constant concentration $(225 \mathrm{pmol} / \mathrm{L})$ of HJP-272. Nonspecific binding was completed by the addition of $300 \mathrm{nmol} / \mathrm{L}$ ET-1. While there is no significant shift in the $\mathrm{kDa}$ value with the addition of the $\mathrm{ET}_{\mathrm{A}}$ receptor antagonist, the $\mathrm{B}_{\max }$ value is more than halved, decreasing from $102,922 \mathrm{cpm}$ to $51,864 \mathrm{cpm}$.

ever, the $B_{\max }$ value is more than halved, decreasing from 102,922 cpm to 51,864 cpm (Figure 2B). These findings, the halving of the $B_{\max }$ and absence of significant shift of the $K_{d}$, suggest that HJP-272 binds noncompetitively to the $\mathrm{ET}_{\mathrm{A}}$ receptor.

\section{Estimation of the $L D_{50}$ Ranges for HJP-272 and HJP-286}

The Acute Toxic Class Method was used to determine the $L_{50}$ for the two compounds effective in controlling preterm birth, HJP-272 and HJP-286, as described in Materials and Methods. According to Organization for Economic Development 423 guidelines, the $L D_{50}$ range for HJP-272 falls into category 5 of the Globally Harmonised System, which is between 1000 and 5000 mg/kg, with a cut-off value of approximately $1500 \mathrm{mg} / \mathrm{kg}$ body weight (Figure 3A).

For HJP-286, no mice died when administered a dose of $200 \mathrm{mg} / \mathrm{kg}$, similar to our results with HJP-272. Also, there was no loss of grasping or loss of righting. However, once the dose was increased to $1000 \mathrm{mg} / \mathrm{kg}$, animals appeared ataxic almost immediately after receiving compound. According to Organization for Economic Development 423 guidelines, the $L_{50}$ range for HJP-286 falls into the Globally Harmonised System category 4 (between 200 and $1000 \mathrm{mg} / \mathrm{kg}$ ) with a cut-off dose of 800 $\mathrm{mg} / \mathrm{kg}$ body weight (Figure 3B).

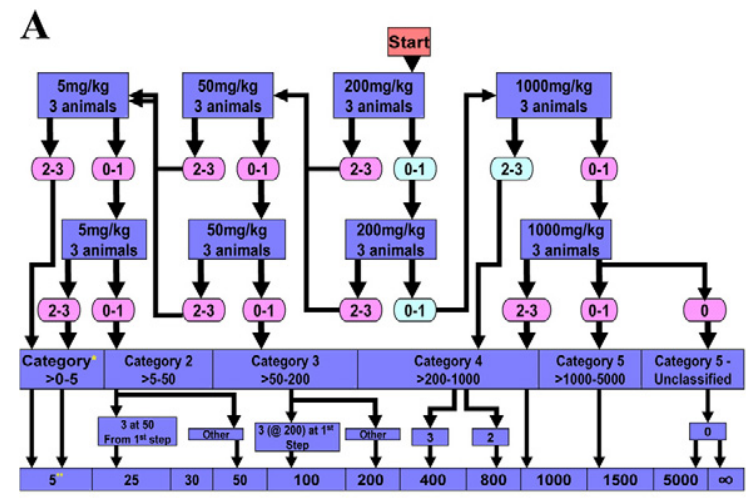

B

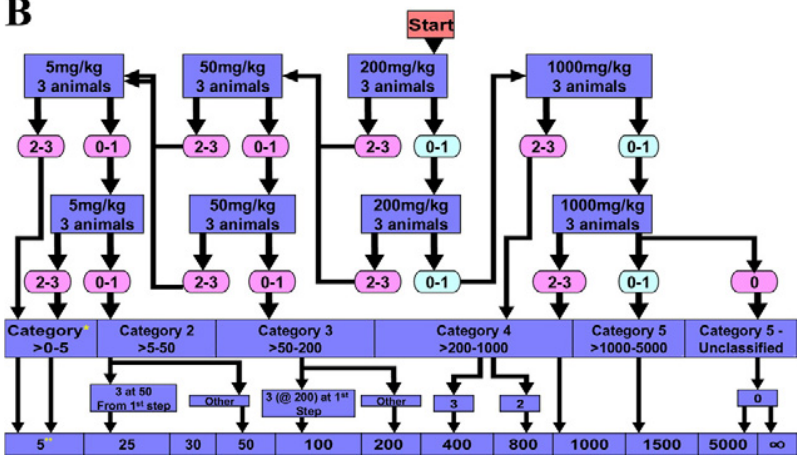

Figure 3. LD50 Ranges for HJP-272 and HJP-286. LD 50 s were determined according to the Organization for Economic Development 423 guidelines (Acute Toxic Class Method). Starting dose was $200 \mathrm{mg} / \mathrm{kg}$. Actual mortality is in shaded green ovals, and theoretical mortality is shown in the pink ovals. HJP-272 falls into category $5(>1000-5000 \mathrm{mg} / \mathrm{kg}$ ) (A) while HJP-286 falls into category $4(>200-1000 \mathrm{mg} / \mathrm{kg})(\mathbf{B})$. *, globally Harmonised Classification System (mg/kg b.w.); **, LD ${ }_{50}$ cut-off (mg/kg b.w.); $\infty$, unclassified.

\section{Rotorod Testing}

Effects on survival and on grasping and righting reflexes were only seen at the higher doses of HJP-286, as shown (Table 1). Interestingly, once the dose of the HJP-286 was reduced to $800 \mathrm{mg} / \mathrm{kg}(n=6)$, animals appeared normal and behaved like the mice in the control and HJP-272 treatment groups, with the exception of one animal that failed the rotorod test after 30 minutes, and at every time point thereafter.

\section{Histology}

Review of hematoxylin and eosin stained tissue sections of brain, heart, lungs, liver, spleen, and gastrointestinal tract, using standard light microscopy and conducted by three blinded observers, shows no signs of acute toxicity in any of the vital organs. Of the mice in the chronic toxicity study, one mouse, receiving a $400 \mathrm{mg} / \mathrm{kg}$ dose of HJP-272, developed chronic hepatitis, histologically (Figure 4, A-D). To determine whether hepatoxicity was a more general chronic adverse reaction, liver sections from all of the mice in the chronic toxicity study were further evaluated for chronic inflammation. The number of lymphoid aggregates, average number of rows of lymphocytes in the three largest aggregates and chronic inflammatory index are shown for all liver sections (Table 2). Data are mean values from three blinded observers. 
Table 1. Effect of $\mathrm{ET}_{\mathrm{A}}$ Receptor Antagonists on Neurologic Function as Assessed by Rotorod Testing

\begin{tabular}{lccc}
\hline Group & $\begin{array}{c}\text { No. of animals } \\
\text { passing rotorod at } \\
t=30 \text { minutes }\end{array}$ & $\begin{array}{c}\text { No. of animals } \\
\text { passing rotorod at } \\
t=2 \text { hours }\end{array}$ & $\begin{array}{c}\text { Loss of righting and loss } \\
\text { of grasping reflexes } \\
\text { at } t=30 \text { minutes }\end{array}$ \\
\hline PBS & $6 / 6$ & $6 / 6^{*}$ & $0 / 6^{*}$ \\
Vehicle & $6 / 6$ & $6 / 6^{*}$ & $0 / 6^{*}$ \\
HJP-272 $(200 \mathrm{mg} / \mathrm{kg})$ & $6 / 6$ & $6 / 6^{*}$ & $0 / 6^{*}$ \\
HJP-272 (1000 mg/kg) & $6 / 6$ & $6 / 6^{*}$ & $0 / 6^{*}$ \\
HJP-286 (200 mg/kg) & $6 / 6$ & $6 / 6^{*}$ & $0 / 6^{*}$ \\
HJP-286 (800 mg/kg) $(1000 \mathrm{mg} / \mathrm{kg})$ & $5 / 6$ & $5 / 6^{*}$ & $1 / 6$ \\
\hline
\end{tabular}

*Animals continued to pass until $t=24$ hours, and did not experience loss of righting or grasping reflexes.

${ }^{\dagger} P<0.05$ when compared with the first five listed groups using Fisher's exact test.

${ }^{\ddagger}$ Animals died at various time points between $t=1.5$ hours and $t=17$ hours. Throughout the observation period, righting and grasping reflexes were never regained.

There was no significant difference in chronic inflammation found between the livers from mice exposed to any of the doses of HJP-272 and the livers from control mice exposed to vehicle.

\section{Use of Novel $E T_{A^{-}}$RAs Delays Delivery in the Mouse Model}

Since the $L D_{50}$ studies revealed that $200 \mathrm{mg} / \mathrm{kg}$ was a safe dose to administer to the animals without any noticeable adverse effect, we opted to use a dose fourfold lower $\left(50 \mathrm{mg} / \mathrm{kg}\right.$ ) to ascertain whether or not the $\mathrm{ET}_{\mathrm{A}}$ receptor antagonists would be able to elicit an effect on preterm birth in lipopolysaccharide-stimulated pregnant animals. The difference in number of mice reaching premature delivery between the group treated with HJP-272 and the group treated with the completely inactive 6-O-
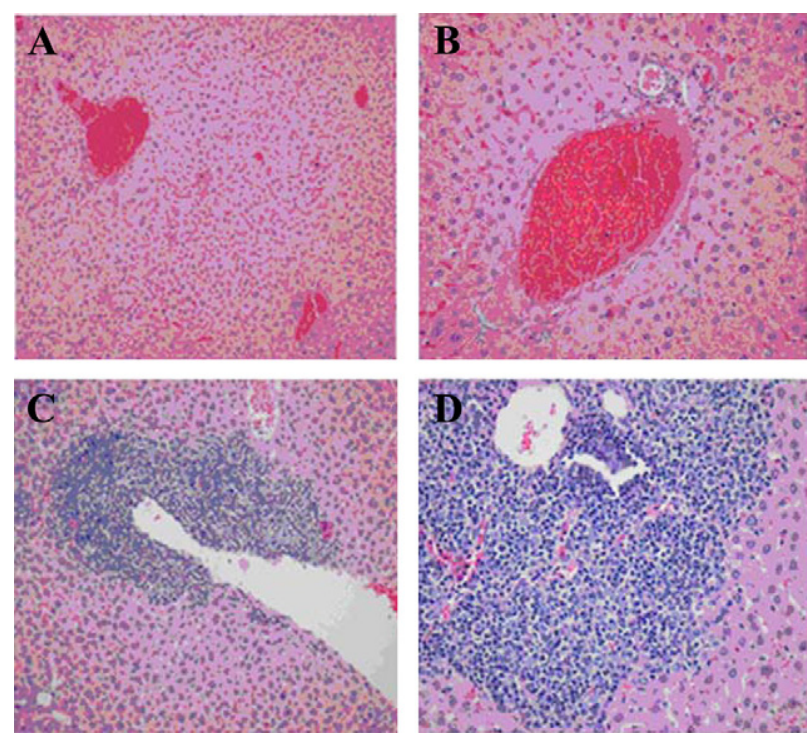

Figure 4. Chronically inflamed hepatic portal region seen in one mouse treated with HJP-272. Mice were administered the compound intraperitoneally and then euthanized 10 days afterward. All vital organs were harvested and preserved in buffered formalin. Sections of the liver from a control mouse, injected with vehicle, are shown in $\mathbf{A}$ (original magnification, $\times 200$ ) and $\mathbf{B}$ (original magnification, $\times \mathbf{4 0 0}$ ). Sections of the liver from a mouse exposed to $400 \mathrm{mg} / \mathrm{kg} \mathrm{HJP}-272$ are shown in $\mathbf{C}$ (original magnification, $\times 200$ ) and $\mathbf{D}$ (original magnification, $\times 400$ ). n-butyl derivative (HJP278) is statistically significant $(P<$ 0.05) (Table 3 and Figure 5A).

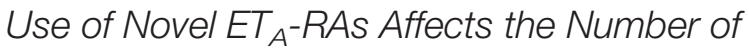 Pups Retained in Utero}

The percentage of pups that were delivered (or alternately, retained in utero) was also tracked. Mice had to be sacrificed within 2 hours of delivering their first pup as per our IACUC's requirements. Mice that did not deliver were sacrificed at $t=24$ hours. All animals were necropsied to confirm pregnancy and to count the number of pups retained in utero. Using $\chi^{2}$ as the method for statistical analysis, treating the mice with either HJP-272, the $-\mathrm{OH}$ analog, or HJP-286, the n-propyl analog, significantly reduced the number of pups dropped secondary to lipopolysaccharide -triggered preterm birth $(P<0.001)$. HJP-278, the $n$-butyl analog, on the other hand, had no effect on the number of pups delivered prematurely (Table 3 and Figure 5B).

\section{Discussion}

In the current work, we use a well established murine model of preterm birth to test the efficacy and toxicity of a novel series of highly selective $\mathrm{ET}_{\mathrm{A}}$ receptor antagonists. The mouse model is advantageous because it affords tight experimental control. The downfall of this

Table 2. Chronic Inflammatory Response in Mouse Hepatic Tissue Resulting from Treatment with HJP-272

\begin{tabular}{lccc}
\hline Treatment & $\begin{array}{c}\text { Number of } \\
\text { lymphoid } \\
\text { aggregates }\end{array}$ & $\begin{array}{c}\text { Number of } \\
\text { rows of } \\
\text { lymphocytes }\end{array}$ & $\begin{array}{c}\text { Chronic } \\
\text { inflammatory } \\
\text { index }\end{array}$ \\
\hline Control & 3.7 & 11.4 & 42.2 \\
Control & 1.3 & 10.2 & 13.3 \\
$200 \mathrm{mg} / \mathrm{kg}$ & 4.7 & 7.2 & 33.8 \\
$200 \mathrm{mg} / \mathrm{kg}$ & 3.7 & 9.7 & 35.9 \\
$200 \mathrm{mg} / \mathrm{kg}$ & 0.3 & 6 & 1.8 \\
$400 \mathrm{mg} / \mathrm{kg}$ & 8.7 & 24 & 208.8 \\
$400 \mathrm{mg} / \mathrm{kg}$ & 1.7 & 21.7 & 36.9 \\
$800 \mathrm{mg} / \mathrm{kg}$ & 1.3 & 11 & 14.3 \\
$800 \mathrm{mg} / \mathrm{kg}$ & 1 & 12 & 12 \\
$800 \mathrm{mg} / \mathrm{kg}$ & 0 & 0 & 0 \\
\hline
\end{tabular}


Table 3. Tocolytic Effects of ET- $\mathrm{R}_{\mathrm{A}}$ Receptor Antagonists

\begin{tabular}{crccc}
\hline Group & $\begin{array}{c}\text { No. of } \\
\text { mice }\end{array}$ & Treatment & $\begin{array}{c}\text { No. of mice } \\
\text { delivering } \\
\text { prematurely (\%) }\end{array}$ & $\begin{array}{c}\text { Pups } \\
\text { delivered } \\
(\%)\end{array}$ \\
\hline 1 & 10 & LPS + PBS & 90.9 & 54.0 \\
2 & 7 & LPS + vehicle & 100 & 58.7 \\
3 & 10 & LPS + HJP-272 & $60.0^{*}$ & $16.1^{\dagger}$ \\
4 & 11 & LPS + HJP-286 & 90.9 & $16.5^{+}$ \\
5 & 9 & LPS + HJP-278 & 100 & 49.2 \\
\hline
\end{tabular}

${ }^{*} P<0.05$ as compared with $n$-butyl analog.

${ }^{\dagger} P<0.001$ as compared with PBS and vehicle controls

model, however, is that mouse pregnancy is multiple, and in mice, progesterone levels decline, a phenomenon that does not occur in humans. ${ }^{4}$ Although we are able to monitor two distinct outcomes in our murine model, ie, percentage of mice delivering and percentage of pups delivered, the former is more relevant to human preterm birth, as most human pregnancies are singleton.

ET-1 is the most potent vasoconstrictor in humans, and is a powerful stimulant of smooth muscle contractions, such as the myometrium of the uterus. ${ }^{12,20}$ It has previously been reported that there are significantly increased levels of circulating ET in the peripheral plasma of women in labor, as compared with non-laboring pregnant women in their third trimester, suggesting that ET plays a direct role in the balance of human uterine quiescence and activity during pregnancy. ${ }^{21}$ In both previous ${ }^{17}$ and current work, we show that in the setting of infection, blockade of ET-1 using analogs from our novel series of 1,3,6trisubstituted-2-carboxy-quinol-4-ones causes significant quiescence of uterine activity at doses in which we see no toxicity in the mother. Our aim in this study was to demonstrate a statistically significant effect on preterm birth, using as low a dose of the novel compounds as possible. Increasing the dose of the compound, however, would likely result in an even more impressive result in terms of number of preterm births prevented.

From the competitive binding data, it can be inferred that HJP-272, the prototype compound in the series, acts as a noncompetitive antagonist and can either bind to the $\mathrm{ET}_{\mathrm{A}}$ receptor or the $\mathrm{ET}_{\mathrm{A}}$ receptor-ET-1 complex, forming inactive complexes of either of the two. ${ }^{22}$ At this time, we do not know if there is any conformational change in the $\mathrm{ET}_{\mathrm{A}}$ receptor on binding with the drug. Our in vivo results show that a direct correlation can be made between efficacy of compound and side chain length of the substituent in the sixth position (Figure 1). Among mice treated with HJP-272, the prototype analog with a hydroxyl group in the sixth position, only $60 \%$ delivered prematurely and those that delivered dropped only $16.1 \%$ of total pups. For HJP-286, the 6-O-n-propyl ana$\log$, there were a total of $90 \%$ of mice that delivered prematurely, dropping only $16.48 \%$ of their pups. Finally, with HJP-278, the 6-O-n-butyl analog, which has the longest side chain, there was $100 \%$ delivery with close to half $(49.2 \%)$ of pups dropped.

Our evaluation of acute and chronic toxicity revealed a single animal in the entire study of 46 mice that had a histological hepatitis. A thorough evaluation of hepatotox-
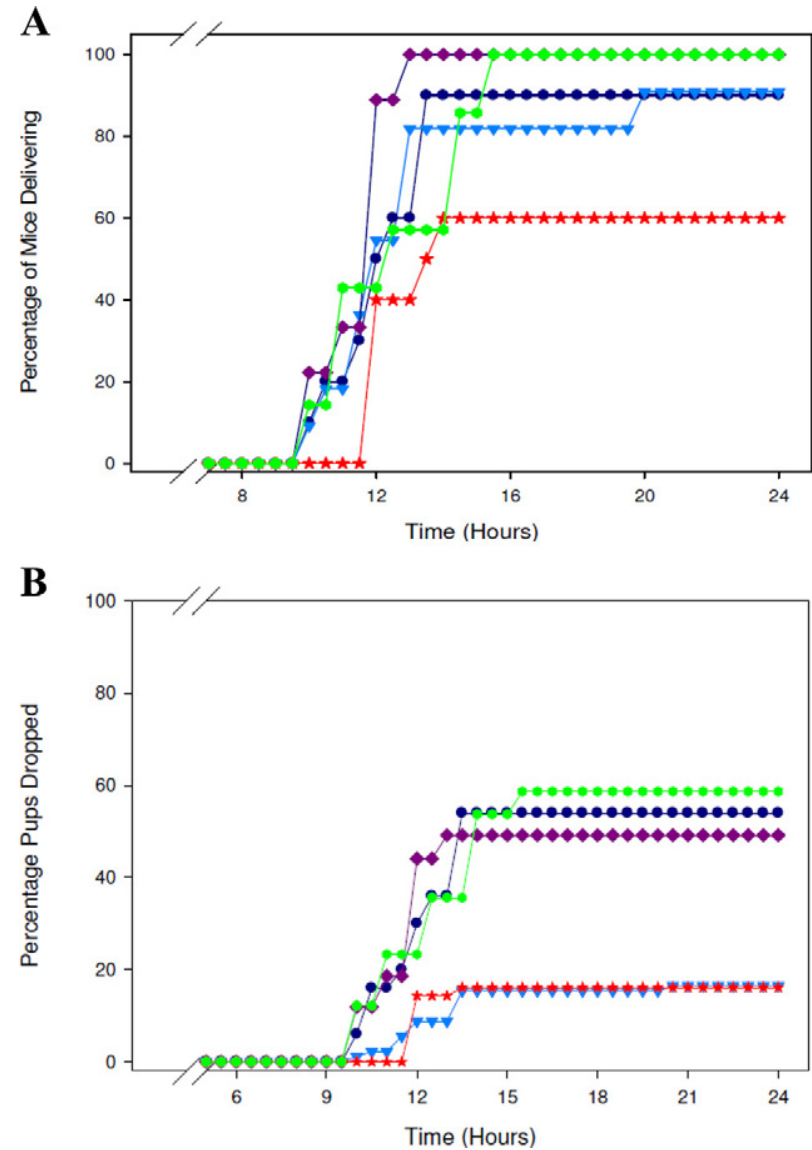

Figure 5. The novel ET receptor antagonists act as tocolytic agents. Mice stimulated with $10.0 \mathrm{mg} / \mathrm{kg}$ of lipopolysaccharide (i.p.) were treated with PBS $(0.5 \mathrm{ml})$, vehicle $(0.5 \mathrm{ml})$, or $50 \mathrm{mg} / \mathrm{kg}$ of HJP-272, HJP-286, or HJP-278. All mice were observed for PTB for a period of 24 hours. The percentage of mice delivering $(\mathbf{A})$ and the percentage of pups dropped $(\mathbf{B})$ over time are shown. After delivering, or at $t=24$ hours for mice that did not deliver, all mice were sacrificed and necropsies were performed to confirm pregnancy and to count the number of pups retained in utero. ${ }^{*} P<0.001$ when compared with controls.

icity, however, revealed no significant increase in liver injury in treated animals, suggesting that the one adverse reaction may have been idiosyncratic. Although we have not completed a formal teratogenic study, gross examination of the fetuses from mothers exposed to either of the compounds as compared with controls reveals no developmental defects.

Over the last 15 years, advancements in neonatology have made it possible for babies born very prematurely, who would have perished previously, to survive. These children, however, often face a lifetime filled with neurological disabilities. Furthermore, the problem of preterm birth is worsening in the United States where, for reasons that are not well understood, the incidence of premature birth has increased by $20 \%$ in the last 15 years.

We demonstrate in this work that two analogs in this series of 1,3,6,-trisubstituted-2-carboxy-quinol-4-ones are effective at preventing premature delivery at doses that are nontoxic. While much controversy surrounds the use of $E T_{A}$ receptor antagonists in pregnant women, the risk of teratogenicity caused by any potential tocolytic agent is minimized, because the period of administration 
is transient, and because the drug would be given well after organogenesis is complete. The developmental anomalies attributed to absence of ET-1 activity that have been described were observed in knockout mice that lacked ET-1 throughout gestation. There are no studies, to our knowledge, showing that transient blockade of ET-1 action, well after organogenesis is complete, is associated with teratogenicity.

While the mechanism of action of our compounds is inhibition of uterine contractions through blockade of ET-1 action, we also have shown, in previous work, that HJP-272 has anti-inflammatory properties. Intraperitoneal administration of this compound in a hamster model of acute lung injury led to a decreased number of neutrophils in bronchoalveolar lavage fluid. ${ }^{23} \mathrm{~A}$ compound with both tocolytic and anti-inflammatory properties is particularly valuable, as some of the morbidity associated with preterm birth, including brain injury and resultant cerebral palsy, is attributed not only to prematurity, but to inflammation itself. An orally active, highly selective $\mathrm{ET}_{\mathrm{A}}$ receptor antagonist that can achieve tocolysis with minimal toxicity, such as HJP-272, has much potential clinical importance and warrants further investigation.

\section{Acknowledgments}

We are grateful to Helen Scaramell and the entire staff of the St. John's Animal Facility for their assistance with the breeding or our mice, Ernestine Middleton for her expert histotechnical assistance, and St. John's University for its support of this work.

\section{References}

1. Lockwood CJ: Predicting premature delivery-no easy task. N Engl J Med 2002, 346:282-284

2. Simhan HN, Caritis SN: Prevention of preterm delivery. N Engl J Med $\mathrm{m}$ 2007, 357:477-487

3. Hayes E, Moroz L, Pizzi L, Baxter J: A cost decision analysis of 4 tocolytic drugs. Am J Obstet Gynecol 2007, 197:383e1-383e6

4. Hirsch $\mathrm{E}$, Wang $\mathrm{H}$ : The molecular pathophysiology of bacterially induced preterm labor: insights from the murine model. J Soc Gynecol Invest 2005, 12:145-155

5. Belt AR, Baldassare JJ, Molnar M, Romero R, Hertelendy F: The nuclear transcription factor NF-kappaB mediates interleukin-1betainduced expression of cyclooxygenase-2 in human myometrial cells. Am J Obstet Gynecol 1999, 181:359-366

6. Romero R, Mazor M, Brandt F: Interleukin-1 alpha and interleukin-1 beta in preterm and term human parturition. Am $\mathrm{J}$ Reprod Immunol 1992, 27:117-123

7. Romero R, Mazor M, Sepulveda W, Avila C, Copeland D, Williams J: Tumor necrosis factor in preterm and term labor. Am J Obstet Gynecol 1992, 166:1576-1587

8. Menon R, Peltier MR, Eckardt J, Fortunato SJ: Diversity in cytokine response to bacteria associated with preterm birth by fetal membranes. Am J Obstet Gynecol 2009, 201:306.e1-306.e6

9. Yanagisawa M, Kurihara H, Kimura S, Tomobe Y, Kobayashi M, Mitsui Y, Yazaki Y, Goto K, Masaki T: A novel potent vasoconstrictor peptide produced by vascular endothelial cells. Nature 1988, 332:411-415

10. Sakurai T, Yanagisawa M, Masaki T: Molecular characterization of endothelin receptors. Trends Pharmacol Sci 1992, 13:103-108

11. Epstein FH: Mechanisms of disease. N Engl J Med 1995, 333: 356-363

12. Attina T, Camidge R, Newby DE, Webb DJ: Endothelin antagonism in pulmonary hypertension, heart failure, and beyond. Heart 2005, 91:825-831

13. Krukier II, Pogorelova TN: Production of vascular endothelial growth factor and endothelin in the placenta and umbilical cord during normal and complicated pregnancy. Bull Exp Biol Med 2006, 141:216-218

14. Ahmad Z, Reznik SE: Immunohistochemical Localization of ECE-1 in the human placenta. Placenta 2000, 21:226-233

15. Koscica KL, Sylvestre G, Reznik SE: The effect of phosphoramidon on inflammation-mediated preterm delivery in a mouse model. Am J Obstet Gynecol 2004, 190:528-531

16. Wang W, Yen H, Chen C, Soni R, Jasani N, Sylvestre G, Reznik SE: The endothelin-converting-enzyme-1/endothelin-1 pathway plays a critical role in inflammation-associated premature delivery in a mouse model. Am J Pathol 2008, 173:1-8

17. Olgun N, Patel HJ, Stephani R, Reznik SE: Effect of the putative novel

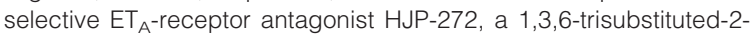
carboxy-quinol-4-one, on infection-mediated premature delivery. Can J Physiol Pharmacol 2008, 86:571-575

18. Kurihara $Y$, Kurihara $H$, Suzuki $H$ : Elevated blood pressure and craniofacial abnormalities in mice deficient in endothelin-1. Nature 1994, 368:703-710

19. Patel HJ, Wang W, Reznik SE, Stephani R: Synthesis of 1,3,6-trisubstituted-2-carboxy-quinol-4-ones as selective $\mathrm{ET}_{\mathrm{A}}$ antagonists and their role in controlling preterm labor in a mouse model. 10th International Conference on Endothelin, Bergamo, Italy, 16-19 September 2007, Abstract P-110

20. Heluy V, Germain G, Fournier T, Ferre F, Breuiller-Fouche M: Endothelin ETA receptors mediate human uterine smooth muscle contraction. Eur J Pharmacol 1995, 285:89-94

21. Usuki S, Saitoh T, Sawamura T, Suzuki N, Shigemitsu S, Yanagisawa M, Goto K, Onda H, Fujino M, Masaki T: Increased maternal plasma concentration of endothelin-1 during labor pain or on delivery and the existence of a large amount of endothelin-1 in the amniotic fluid. Gynecol Endocrinol 1990, 4:85-97

22. Horton RH, Moran LA, Scrimgeour KG, Perry MD, Rawn JD: Mechanisms of enzymes. Principles of Biochemistry, ed 4. Upper Saddle River, NJ, Prentice Hall, 2006, pp 158-191

23. Bhavsar TM, Cerreta JM, Liu M, Reznik SE, Cantor JO: Phosphoramidon, an endothelin-converting enzyme-1 inhibitor, attenuates lipopolysaccharide- induced acute lung injury. Exp Lung Res 2008, 34:141-154 